\title{
PERLINDUNGAN HUKUM TERHADAP KONSUMEN AKIBAT WANPRESTASI PENJUAL DALAM TRANSAKSI ELEKTRONIK
}

\author{
Serena Ghean Niagara \\ Fakultas Hukum Universitas Pamulang \\ doseno2436@unpam.ac.id
}

\begin{abstract}
Buy and sell transactions in electronic transactions are legal acts performed using computers, computer networks, and other electronic media. Arrangement of agreement on buying and selling in electronic transactions is equal to buying and selling in general, namely the Civil Code law, Law No. 8 of 1999 on consumer protection and law No. 11 year 2008 on Information and electronic transactions or also referred to as the ITE LAW. Section 1338 (1) of the Civil Code explains if a legally-made agreement applies as a law to which it is made. That is, the agreement is valid and binding for the parties legally. But in the fact that online trading on the exercise of the rights and obligations of the parties does not match what is promised. A lot of tort is generally done by the seller.
\end{abstract}

Keywords: legal protection, tort, electronic transactions

\begin{abstract}
ABSTRAK
Transaksi jual beli dalam transaksi elektronik ialah perbuatan hukum yang dilakukan dengan menggunakan komputer, jaringan komputer, dan atau media elektronik lainnya. Pengaturan perjanjian mengenai jual beli dalam transaksi elektronik sama dengan jual beli pada umumnya, yakni Kitab Undang-Undang Hukum Perdata, Undang-Undang Nomor 8 tahun 1999 tentang Perlindungan Konsumen serta Undang-Undang No. 11 tahun 2008 tentang Informasi dan Transaksi Elektronik atau juga disebut dengan UU ITE. Pasal 1338 (1) Kitab Undang-Undang Hukum Perdata menjelaskan jika perjanjian yang di buat secara sah berlaku sebagai undang-undang bagi yang membuatnya. Artinya, perjanjian tersebut berlaku dan mengikat bagi para pihak secara hukum. Namun dalam kenyataanya jual beli secara online pada pelaksanaan hak dan kewajiban para pihak tidak sesuai dengan apa yang diperjanjikan. Banyak terjadi wanprestasi yang umumnya dilakukan oleh pihak penjual.
\end{abstract}

Kata Kunci : Perlindungan Hukum, Wanprestasi, Transaksi Elektronik 


\section{PENDAHULUAN}

Pada mulanya transaksi bisnis hanya dilakukan secara langsung yaitu dengan bertatap muka antara penjual dan pembeli. Namun seiring dengan perkembangan zaman dan pemakaian internet dan bisnis melalui internet berkembang sangat pesat, sehingga lahirlah jual-beli secara online, hingga sektor hukum pun diminta untuk turun tangan sehingga dalam bisnis melalui internet seperti itu, dapat dicapai ketertiban dan kepastian dalam transaksi bisnis. Transaksi bisnis lewat internet (dengan menggunakan perangkat elektronik) ini sering disebut dengan transaksi elektronik atau electronic commerce (E-Commerce).

Jual beli online adalah suatu kegiatan jual beli di mana penjual dan pembelinya tidak harus bertemu untuk melakukan negosiasi dan transaksi. Kemudian yang digunakan oleh penjual dan pembeli untuk berkomunikasi yaitu melalui chat, komputer, telepon, sms dan sebagainya.

Didalam transaksi jual beli online, penjual dan pembeli membutuhkan pihak ketiga untuk melakukan penyerahan barang yang dilakukan oleh pedagang dan penyerahan uang yang dilakukan oleh pembeli. Seperti jual beli di atas, kita juga bisa melakukan jual beli online melalui suatu forum jual beli online atau situs jual beli online yang sudah menyediakan banyak barang untuk diperjual belikan. Tidak hanya itu, untuk mempelancar dan mengamankan transaksi, ada baiknya bila kita menggunakan jasa pihak ketiga untuk menyimpan uang kita secara aman.

Kemudahan dalam melakukan transaksi elektronik membuat transaksi ini semakin digemari konsumen terutama bagi para pekerja yang sibuk hingga tidak memiliki waktu luang dan tidak sempat mampir ke Mall untuk sekedar belanja. Namun sangat disayangkan bahwa transaksi jual-beli yang berjalan saat ini banyak yang mengecewakan para konsumen dan banyak terjadi pelanggaran hak-hak konsumen dalam bentuk wanprestasi yang dilakukan oleh pihak penjual toko online. Bentuk wanprestasi yang sering terjadi adalah penjual memberikan barang yang tidak sesuai dengan yang diperjanjikan sebelumnya dengan konsumen atau tidak memberikan barang sesuai dengan yang dijadikan obyek jual-beli.

Perkembangan perekonomian dewasa ini, telah memacu tumbuhnya sektor produksi dan perdagangan yang dalam kenyataan secara tidak langsung menciptakan kekuatan posisi pelaku usaha di satu sisi, dan menempatkan konsumen pada sisi yang lain. Sebagian pelaku usaha dalam melakukan kegiatannya seringkali mengabaikan kepentingan konsumen. Mengingat posisinya seperti itu, konsumen sering "terpaksa” menerima suatu produk barang/jasa, meskipun tidak sesuai dengan yang diinginkan (wanprestasi). (Aman Sinaga, 2001; 26)

Wanprestasi oleh pihak penjual toko online juga memperlemah posisi 
konsumen. Wanprestasi mempunyai akibat bagi konsumen, sebab wanprestasi adalah ingkar janji yang tertuang dalam perjanjian, sehingga dapat menimbulkan kerugian bagi konsumen.

Maka dari itu, dalam hubungan antara pihak penjual toko online dengan konsumen, konsumen memiliki risiko yang lebih besar daripada pihak penjual toko online, dengan kata lain hak-hak konsumen sangat rentan. Disebabkan posisi tawar konsumen yang lemah, maka hak-hak konsumen sangat riskan untuk dilanggar. (Aman Sinaga, 2001; 243)

\section{METODE PENELITIAN}

Metodologi yang penulis gunakan adalah metodologi hukum normatif. Penelitian normatif atau penelitian hukum kepustakaan adalah penelitian hukum dengan menggunakan data sekunder yaitu data yang diperoleh dari bahan-bahan pustaka. Dalam penelitian hukum normatif ini, penulis mengumpulkan data berupa data-data sekunder yang diperoleh dari buku-buku, Undang-Undang serta sumber kepustakaan lainnya.

\section{PERMASALAHAN}

Berdasarkan pemaparan yang dikemukakan dalam latar belakang diatas maka penulis menitikberatkan pada dua permasalahan yaitu pertama, Bagaimanakah pelaksanaan perlindungan hukum terhadap konsumen akibat wanprestasi penjual dalam transaksi elektronik? Kedua, Apakah diperlukan pembaharuan hukum dalam pelaksanaan perlindungan hukum terhadap konsumen akibat wanprestasi penjual dalam transaksi elektronik?

\section{PEMBAHASAN}

Pelaksanaan Perlindungan Hukum

$\begin{array}{lrl}\text { Terhadap } & \text { Konsumen } & \text { Akibat } \\ \text { Wanprestasi } & \text { Penjual } & \text { Dalam } \\ \text { Transaksi Elektronik } & \end{array}$

Pada dasarnya pelaksanaan proses transaksi jual beli secara elektronik tidak jauh berbeda dengan transaksi jual beli secara langsung. Pelaksanaan transaksi jual beli secara elektronik ini dilakukan dalam beberapa tahap, yaitu :

1. Penawaran, yang dilakukan oleh pelaku usaha melalui website pada internet. Pelaku usaha menyediakan data-data produk yang dijual. Sehingga dengan penawaran melalui media internet hanya dapat terjadi apabila konsumen membuka situs yang menampilkan sebuah produk barang melalui internet tersebut.

2. Penerimaan, dapat dilakukan tergantung penawaran yang terjadi. Apabila penawaran dilakukan melalui e-mail address, maka penerimaan dilakukan melalui e-mail, karena penawaran hanya ditujukan pada sebuah email yang dituju sehingga hanya pemegang e-mail tersebut yang dituju. Setiap orang yang berminat untuk membeli produk yang ditawarkan itu dapat membuat 
kesepakatan dengan pelaku usaha yang menawarkan produk tersebut. Pada transaksi jual beli secara elektronik, khususnya melalui website, biasanya calon konsumen akan memilih jenis barang yang ditawarkan oleh pelaku usaha, dan jika konsumen itu tertarik untuk membeli salah satu barang yang ditawarkan, maka barang tersebut akan disimpan terlebih dahulu didalam keranjang belanja pada website tersebut hingga konsumen merasa yakin akan pilihannya, selanjutnya konsumen akan memasuki tahap pembayaran.

3. Pembayaran, dapat dilakukan baik secara langsung maupun tidak langsung, misalnya melalui fasilitas internet, namun masih tetap bertumpu pada sistem keuangan nasional, yang mengacu pada system keunagan lokal. Klasifikasi cara pembayaran dapat diklasifikasikan sebagai berikut :

a. Transaksi model Automatic Teller Machine (ATM), sebagai transaksi yang hanya melibatkan institusi finansial dan pemegang account yang akan melakukan pengambilan atau mendeposit uangnya dari account masing-masing;

b. Pembayaran dengan perantara pihak ketiga, umumnya merupakan proses pembayaran yang menyangkut debit, kredit ataupun cek masuk. Metode pembayaran yang dapat digunakan antara lain : sistem pembayaran melalui kartu kredit on line serta sistem pembayaran check in line.

Apabila kedudukan pelaku usaha dengan konsumen berbeda, maka pembayaran dapat dilakukan melalui cara account to account atau pengalihan dari rekening konsumen kepada rekening pelaku usaha. Berdasarkan kemajuan teknologi, pembayaran dapat dilakukan melalui kartu kredit dengan cara memasukan nomor kartu kredit pada formulir yang disediakan oleh penjual dalam penawaran melalui website. Pembayaran dalam transaksi jual beli secara elektronik ini sulit untuk dilakukan secara langsung, karena terdapat perbedaan lokasi dengan pelaku usaha dengan konsumen, walaupun dimungkinkan untuk dilakukan.

4. Pengiriman, suatu proses yang dilakukan setelah melakukan pembayaran atas barang yang ditawarkan oleh pelaku usaha kepada konsumen. Dalam hal ini konsumen berhak atas penerimaan barang yang telah dibeli. Pada kenyataannya, pengiriman barang yang telah dibeli konsumen dapat dikirim secara langsung dan 
otomatis melalui jasa pengiriman barang.

Berdasarkan proses jual beli secara elektronik yang telah diuraikan diatas menggambarkan bahwa jual beli melalui media internet dapat dilakukan, sehingga orang yang saling berjauhan atau berada pada lokasi yang berbeda tetap dapat melakukan transaksi jual beli tanpa harus bersusah payah untuk saling bertemu secara langsung, sehingga dapat meningkatkan efektivitas dan efesiensi waktu serta biaya baik bagi pihak pelaku usaha maupun konsumen. Transaksi jual beli secara elektronik ini pun sudah terlihat memenuhi syarat sah perjanjian sebagaimana ditentukan dalam Pasal 1320 Kitab Undang-Undang Hukum Perdata dengan catatan harus disertai dengan asas kepercayaan antara para pihak.

Suatu perjanjian dapat terlaksana dengan baik apabila para pihak telah memenuhi prestasinya masing-masing seperti yang telah diperjanjikan tanpa ada pihak yang dirugikan. Tetapi adakalanya perjanjian tersebut tidak terlaksana dengan baik karena adanya wanprestasi yang dilakukan oleh salah satu pihak.

Perkataan wanprestasi berasal dari bahasa Belanda, yang artinya prestasi buruk.Adapun yang dimaksud wanprestasi adalah suatu keadaan yang dikarenakan kelalaian atau kesalahannya, tidak dapat memenuhi prestasi seperti dalam perjanjian (Nindyo Pramono, 2003; 21) dan bukan dalam keadaan memaksa.
Menurut kamus hukum, wanprestasi berarti kelalaian, kealpaan, cidera janji, tidak menepati kewajibannya dalam perjanjian (Subekti dan Tjitrosoedibio, 1996; 110). Dengan demikian, wanprestasi adalah suatu keadaan dimana seorang tidak memenuhi atau melaksanakan prestasi sebagaimana telah ditetapkan dalam suatu perjanjian. Wanprestasi (lalai/alpa) dapat timbul karena :

1. Kesengajaan atau kelalaian konsumen itu sendiri

2. Adanya keadaan memaksa (overmacht)

Adapun bentuk wanprestasi dari pihak penjual dalam jual beli secara online, yaitu :

a. Tidak melakukan apa yang disanggupi akan dilakukan;

Pihak penjual tidak melakukan pengiriman barang sebagaimana yang sudah diperjanjikan dalam transaksi jual beli secara online.

b. Melaksanakan apa yang dijanjikannya tetapi tidak sebagaimana dijanjikannya;

Pihak penjual melakukan pengiriman barang namun barang tidak sesuai dengan apa yang dipesan oleh pembeli.

c. Melakukan apa yang dijanjikannya tetapi terlambat;

Pihak penjual melakukan pengiriman barang yang telah dipesan oleh pembeli namun terjadi keterlambatan pengiriman 
barang yang tidak diketahui oleh pihak pembeli.

d. Melakukan sesuatu yang menurut perjanjian tidak boleh dilakukan.

Pihak penjual melakukan pengiriman barang yang telah dipesan oleh pembeli namun barang yang dikirim ialah barang yang cacat, barang yang seharusnya tidak boleh diperjualbelikan.

Adapun cara penyelesaian wanprestasi dalam jual beli secara online yaitu :

a) Para pihak dapat menyelesaikan sengketa sesuai dengan kesepakatan kedua belah pihak yang sudah dicantumkan didalam peraturan dalam perjanjian jual beli secara online tersebut.

b) Para pihak juga dapat menyelesaikan sengketa melalui arbitrase, atau lembaga penyelesaian sengketa alternatif lainnya sesuai dengan ketentuan Peraturan Perundang-Undangan. (Pasal 39 ayat (2) Undang-Undang Nomor 11 Tahun 2008 tentang Informasi dan Transaksi Elektronik)

c) Penyelesaian sengketa diluar pengadilan diselenggarakan untuk mencapai kesepakatan mengenai bentuk dan besarnya ganti rugi dan/atau mengenai tindakan tertentu untuk menjamin tidak akan terjadi kembali atau tidak akan terulang kembali kerugian yang diderita oleh konsumen (Pasal 47 Undang-Undang Nomor 8

Tahun1999 tentang Perlindungan Konsumen)

d) Salah satu pihak yang merasa dirugikan dapat mengajukan gugatan terhadap pihak yang menyelenggarakan Sistem Elektronik dan/atau menggunakan Teknologi Informasi yang menimbulkan kerugian dan diajukan ke Pengadilan Negeri setempat. (Pasal 38 ayat (1) Undang-Undang Nomor 11 Tahun 2008 tentang Informasi dan Transaksi Elektronik).

e) Masyarakat juga dapat mengajukan gugatan secara perwakilan terhadap pihak yang menyelenggarakan sistem elektronik dan/atau menggunakan teknologi informasi yang berakibat merugikan masyarakat, sesuai dengan ketentuan peraturan perundang-undangan. (Pasal 38 ayat (1) Undang-Undang Nomor 11 Tahun 2008 tentang Informasi dan Transaksi Elektronik).

f) Penyelesaian sengketa melalui pengadilan mengacu pada ketentuan tentang peradilan umum yang berlaku (Pasal 48 Undang-Undang Nomor 8 Tahun 1999 tentang Perlindungan Konsumen)

Namun dalam penyelesaian permasalahan dalam bentuk wanprestasi 
penjual dalam transaksi elektronik, diperlukan pembaharuan hukum yang lebih spesifik yaitu diperlukan pembaharuan hukum dalam memberikan perlindungan hukum terhadap konsumen tidak hanya kepada Warga Negara Indonesia, tapi juga memberikan perlindungan hukum kepada konsumen Warga Negara Asing yang berada di Indonesia. Seiring dengan perkembangan yang pesat dalam transaksi elektronik atau yang sering disebut E-Commerce, tidak berarti peraturan mengenai transaksi jual beli pada dunia E-Commerce berkembang pula. Bahkan peraturan yang ada masih memiliki kecenderungan untuk berpihak kepada pihak penjual daripada melindungi hak konsumen.

Dari kasus yang banyak terjadi diatas mengakibatkan posisi pihak pembeli atau pihak konsumen menjadi lemah dan hanya bisa menerima dengan apa yang telah dilakukan pihak penjual. Maka dari itu, diperlukan peraturan yang baru mengenai perlindungan konsumen dalam transaksi elektronik secara spesifik. Dengan begitu posisi pihak pembeli atau pihak konsumen tidak menjadi lemah dan bahkan posisinya dapat menjadi seimbang dengan pihak penjual.

\section{PENUTUP}

\section{Kesimpulan}

Wanprestasi yang terjadi pada transaksi elektronik atau sering disebut dengan E-Commerce biasanya dilakukan oleh pihak penjual. Hal ini mengakibatkan merugikan pihak pembeli. Adapun hal-hal yang dapat dilakukan oleh pihak pembeli untuk menyelesaikan kasus wanprestasi yang dilakukan pihak penjual yaitu melakukan penyelesaian sengketa diluar pengadilan hingga mengajukan gugatan ke pengadilan yang berwenang. Namun dalam perkembangan saat ini, diperlukan pembaharuan hukum yang mengatur transaksi elektronik lebih spesifik sehingga tidak akan terjadi lagi permasalahan mengenai wanprestasi dalam transaksi elektronik.

\section{Saran}

Bagi pemerintah seharusnya memberikan efek jera dalam penanganannya dikarenakan perlu ada tindakan tegas baik dalam konteks implementasi ataupun sesuatu yang berkaitan dengan kepentingan public dimana ini memerlukan suatu daya analisis baik dalam proses perencanaan, pelaksanaan, serta pengawasan yang perlu adanya pengakomodiran yang bersinergi dan terintegarsi sehingga konsumen dalam hal ini tidak merasa untuk dirugikan.

\section{DAFTAR PUSTAKA}

\section{Aman Sinaga, Pemberdayaan Hak-Hak} Konsumen di Indonesia. Direktorat Perlindungan Konsumen DITJEN Perdagangan dalam Negeri Departemen Perindustrian dan Perdagangan bekerjasama dengan Yayasan Gemainti, Jakarta, 2001, 
Haris Faulidi Asnawi, Transaksi Bisnis Ecommerce Perspektif Islam, Magistra Insania Press, Yogyakarta, 2004,

Mariam Darus Badrulzaman, Kompilasi Hukum Perikatan, PT. Citra Aditya Bakti, 2001, Bandung,

Munir Fuady, Pengantar Hukum Bisnis Menata Bisnis Modern di Era Global. Bandung. PT. Citra Aditya Bakti, 2008.

Nindyo Pramono, Hukum Komersil cet II, Pusat Penerbitan UT, Jakarta, 2003 ,

Panggih P Dwi Atmojo, Internet Untuk Bisnis I, Dirkomnet Training, Yogyakarta, 2002,

R. Subekti, Pokok-Pokok Hukum Perdata, cet XXIX, PT Inter Masa, Jakarta, 2001,

R. Wirjono Prodjodikoro, Hukum Perkawinan Di Indonesia, Cet.IV, Sumur Bandung, Bandung, 1960,

Subekti dan Tjitrosoedibio, Kamus Hukum, Pradnya Paramita, Jakarta, 1996. 
